\title{
Epigraphik und Neues Testament
}

\author{
Hrsg. v. Thomas Corsten, Markus Öhler u. Joseph Verheyden
}

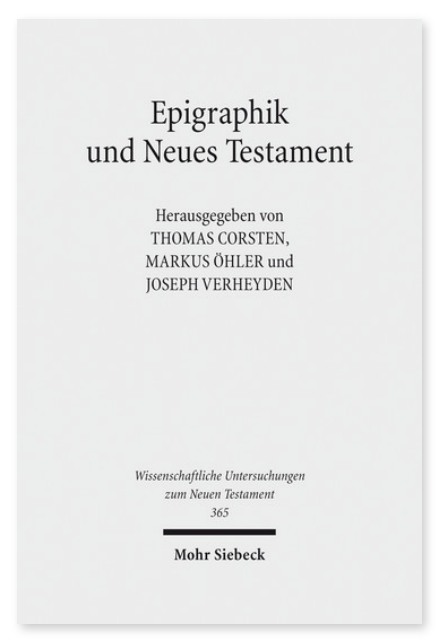

2016. VIII, 213 Seiten. WUNT I 365

ISBN 978-3-16-154749-2

DOI 10.1628/978-3-16-154749-2

eBook PDF 114,00€

ISBN 978-3-16-153508-6

Leinen $114,00 €$
Unter den Ansätzen, das frühe Christentum innerhalb seines lebensweltlichen Kontexts zu verstehen, ist die Untersuchung des epigraphischen Materials noch nicht fortgeschritten, sodass ein weites Forschungsfeld brach liegt. Der vorliegende Sammelband mit Beiträgen einer Konferenz an der Universität Wien vom Februar 2014 macht einen wichtigen Schritt bezüglich einer verbesserten Wahrnehmung dieses wesentlichen Bereichs antiker Dokumente. Dabei wirken neutestamentliche und epigraphische Blickwinkel und Forschungsansätze eng zusammen. So finden sich in diesem Band Erörterungen methodischer Fragen, die eine systematische Bearbeitung des inschriftlichen Materials im Blick haben, und Einzelstudien, die sich mit Gattungen von Inschriften befassen oder thematischen Ansätzen folgen.

Inhaltsübersicht

Joseph Verheyden/Markus Öhler/Thomas Corsten: Introduction - Walter Ameling: Neues Testament und Epigraphik aus der Perspektive der epigraphischen Forschung - Peter Arzt-Grabner: Die Auswertung inschriftlicher Zeugnisse für die neutestamentliche Exegese. Erfahrungen, Chancen und Herausforderungen - Thomas Corsten: Die Rolle der Onomastik für die Erforschung des frühen Christentums. Ein einführender Überblick - Hans Taeuber: Ephesische Graffiti als Zeugnisse des Lebensgefühls in der hohen Kaiserzeit - Eva Ebel: Vergöttlichte Kaiser am Straßenrand. Die Bedeutung epigraphischer Zeugnisse für die Sichtbarkeit der Verbindung von Religion und Politik im Imperium Romanum und für eine kaiserkritische Lektüre neutestamentlicher Schriften - Richard S. Ascough: Carving Out Public Space. тóno Inscriptions and Early Christ Groups - Imre Peres: Die eschatologischen Aussagen kaiserzeitlicher Grabinschriften - John S. Kloppenborg: Epigraphy, Papyrology and the Interpretation of the New Testament: Member Contributions to the Eucharist - Markus Öhler: Sünde, Bekenntnis und Sühne in kleinasiatischen »Beichtinschriften« und dem 1. Johannesbrief

Thomas Corsten is Professor for Greek History and Epigraphy at the University of Vienna and head of the working group Epigraphy at the Austrian Academy of Sciences.

Markus Öhler Geboren 1967; Studium der Ev. Theologie und Universitätsassistent in Wien; FWF-Stipendiat in Tübingen; Gastprofessor in Hamburg; seit 2011 Professor am Institut für Neutestamentliche Wissenschaft der EvangelischTheologischen Fakultät der Universität Wien. https://orcid.org/0000-0003-4294-9778

Joseph Verheyden is Professor of New Testament Studies in the Faculty of Theology and Religious Studies at the KU Leuven. https://orcid.org/0000-0002-8646-5233

Jetzt bestellen:

https://mohrsiebeck.com/buch/epigraphik-und-neues-testament-9783161547492?no_cache=1

order@mohrsiebeck.com

Telefon: +49 (0)7071-923-17

Telefax: $+49(0) 7071-51104$ 